\title{
Chemical composition and antiprotozoal activities of Colombian Lippia spp essential oils and their major components
}

\author{
Patricia Escobar ${ }^{1} /{ }^{+}$, Sandra Milena Leal', Laura Viviana Herrera', \\ Jairo Rene Martinez ${ }^{2}$, Elena Stashenko² \\ ${ }^{1}$ Centro de Investigación de Enfermedades Tropicales, Departamento de Ciencias Básicas ${ }^{2}$ Centro de Investigación en Biomoléculas, \\ Escuela de Química, Universidad Industrial de Santander, Bucaramanga, Colômbia
}

The chemical composition and biological activities of 19 essential oils and seven of their major components were tested against free and intracellular forms of Leishmania chagasi and Trypanosoma cruzi parasites as well as Vero and THP-1 mammalian cell lines. The essential oils were obtained from different species of Lippia, a widely distributed genus of Colombian plants. They were extracted by microwave radiation-assisted hydro-distillation and characterised by GC-FID and GC-MS. The major components were geranial, neral, limonene, nerol, carvacrol, p-cymene, $\gamma$-terpinene, carvone and thymol. The essential oil of Lippia alba exhibited the highest activity against T. cruzi epimastigotes and intracellular amastigotes with an $I C_{50}$ of $5.5 \mu \mathrm{g} / \mathrm{mL}$ and $12.2 \mu \mathrm{g} / \mathrm{mL}$, respectively. The essential oil of Lippia origanoides had an $I C_{50}$ of $4.4 \mu \mathrm{g} / \mathrm{mL}$ in L. chagasi promastigotes and exhibited no toxicity in mammalian cells. Thymol $\left(I C_{50} 3.2 \pm 0.4 \mu \mathrm{g} / \mathrm{mL}\right)$ and S-carvone $\left(I C_{50} 6.1 \pm 2.2 \mu \mathrm{g} / \mathrm{mL}\right)$, two of the major components of the active essential oils, were active on intracellular amastigotes of T. cruzi infected Vero cells, with a selective index greater than 10. None of the essential oils or major components tested in this study was active on amastigotes of L. chagasi infected THP-1 cells.

Key words: essential oils - Lippia - cytotoxic activity - Leishmania chagasi - Trypanosoma cruzi - Colômbia

The genus Lippia (Verbenaceae) includes approximately 200 species of plants from the tropics of Africa as well as South and Central America. Infusions of the leaves, aerial parts or flowers are traditionally utilised as topical lotion for respiratory, gastrointestinal and skin disorder treatments. Some species of Lippia are composed of a wide variety of chemically variable, volatile compounds that present biological properties (Pascual et al. 2001, Meneses et al. 2009, Mesa et al. 2009).

Protozoal diseases, such as leishmaniasis and Chagas disease, constitute a major public health problem in Latin American countries. There are not very many drug treatment options and most options have problems associated with their use. Plants and their natural products constitute good sources of interesting lead compounds that could be potentially active against Leishmania or Trypanosoma (Croft et al. 2005). Essential oils from aromatic plants such as Chenopodium ambrosioides (Monzote et al. 2007), Origanum vulgare, Thymus vulgaris (Santoro et al. 2007b), Melissa officinalis (Mikus et al. 2000), Ocimum gratissimum (Ueda-Nakamura et al. 2006), Salvia cilicica (Tan et al. 2002), Salvia gilliessi (Sanchez et al. 2006), Rosmarinus officinalis (Braga et al. 2007) and Croton cajucara (Euphorbiaceae) (Rosa et al. 2003) have been found to be effective against Leish-

Financial support: Instituto Colombiano para el Desarrollo de la Ciencia y la Tecnología Francisco José de Caldas COLCIENCIAS (RC432-2004-CENIVAM), Universidad Industrial de Santander

+Corresponding author: pescobarwww@yahoo.co.uk

Received 13 October 2009

Accepted 5 February 2010 mania spp and Trypanosoma cruzi parasites. Although essential oils originating from Lippia spp have shown antimicrobial activities, their activity against $T$. cruzi and Leishmania has not been determined. The aims of this study were to determine the chemical composition of essential oils obtained from Lippia species grown in Colombia and to assess their in vitro activity against $T$. cruzi and Leishmania chagasi parasites as well as Vero and THP-1 mammalian cells.

\section{MATERIALS AND METHODS}

Plants, essential oil extraction and chemical characterisation - Nineteen essential oil samples were extracted from the aerial parts of five different species of Lippia (Table I). Plants were collected from their natural habitats during 2005-2006 in different places of Colombia. Taxonomic identification was performed by Dr. José Luis Fernández at the Instituto de Ciencias Naturales, Universidad Nacional, Bogotá, Colombia. Voucher specimens were deposited in the Colombian National Herbarium. The essential oils were obtained by a microwave radiation-assisted hydrodistillation technique and analysed by GC-MS (Stashenko et al. 2004). For their chromatographic analysis, individual essential oil samples $(50 \mu \mathrm{L})$ were mixed with $n$-tetradecane $(2 \mu \mathrm{L}$, internal standard) and diluted with dichloromethane to a final volume of $1.0 \mathrm{~mL}$. Relative amounts of essential oil constituents were reported as means of triplicate analyses. Compound identification was based on chromatographic (retention times and indices, use of standard compounds) and spectroscopic (mass spectra interpretation, comparison with databases and standard compounds) criteria. Analyses were performed in a gas chromatograph (Agilent Technologies 6890 Plus, Palo 
TABLE I

List of selected plants and anti-protozoal and mammalian cell activities

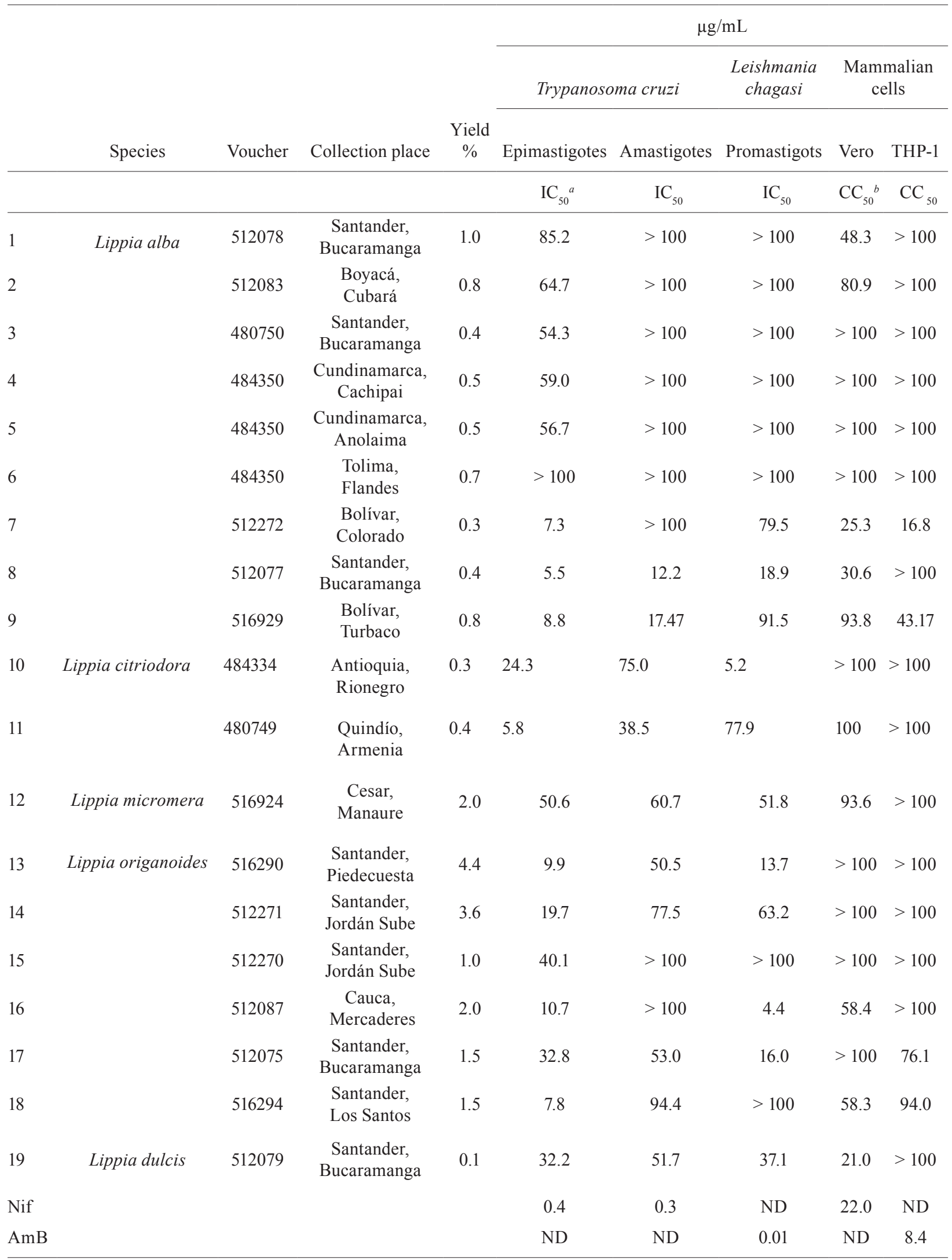

$a$ : inhibitory concentration; ; $b$ : cytotoxic concentration; AmB: amphotericin B (L. chagasi referential drug); Nif: nifurtimox (T. cruzi referential drug). 
Alto, CA, USA) coupled to a mass selective detector (EI, $70 \mathrm{eV}$ ) (Agilent Technologies 5973), split/splitless injector (1:50 split ratio) and a data system (HP ChemStation 1.05) with WILEY 138K, NIST 2002 and QUADLIB 2004 mass spectra libraries. A DB-5MS fused silica capillary column (J\&W Scientific, Folsom, CA, USA) of $60 \mathrm{~m} \mathrm{x}$ $0.25 \mathrm{~mm} \times 0.25 \mu \mathrm{m}$ (df) was used. The GC oven temperature was programmed from $45^{\circ} \mathrm{C}(15 \mathrm{~min})$ to $250^{\circ} \mathrm{C}(15$ $\mathrm{min}$ ) at a rate of $5^{\circ} \mathrm{C} / \mathrm{min}$. The temperatures of the ionisation chamber and the transfer line were set at $230^{\circ} \mathrm{C}$ and $285^{\circ} \mathrm{C}$, respectively. Mass spectra and reconstructed ion currents (chromatograms) were obtained by automatic scanning at $5.19 \mathrm{scan} / \mathrm{s}$, within the mass range $\mathrm{m} / \mathrm{z} 30$ 300. The results appear in Table II. The resulting essential oils were not checked for the presence of endotoxins.

Parasites, cells, major compounds and reference drugs - Epimastigotes of T. cruzi (Strain 215, KP Luna CINTROP) were cultured in liver infusion tryptose medium supplemented with 5\% heat-inactivated foetal calf serum (hiFCS). Promastigotes of L. chagasi (MHOM/ BR/74/PP75) were cultured at $28^{\circ} \mathrm{C}$ in Schneider's Drosophila medium supplemented with $10 \%$ hiFCS. Vero cells (ATCC) and human acute monocytic leukaemia cell line THP-1 cells (ATCC) were cultured in RPMI 1640 medium supplemented with $10 \%$ hiFCS at $37^{\circ} \mathrm{C}$ in a $5 \% \mathrm{CO}_{2}-95 \%$ air mixture. THP-1 cells were transformed to adherent macrophages with phorbol myristate acetate (Sigma, St. Louis, USA) for $48 \mathrm{~h}$ at $37^{\circ} \mathrm{C}$ before the experiments. The major components evaluated were geranial, $S$-(-)-limonene, $R$-(+)-limonene, carvacrol, $p$ cymene, $\gamma$-terpinene, $S$-(+)-carvone, $R$-(-)-carvone and thymol, all obtained commercially from Sigma-Aldrich (Darmstadt, Germany). Nifurtimox and amphotericin B (AmB) were used as reference drugs. Stock solutions of essential oils and reference drugs were prepared in DMSO (Carlo-Ebra, Rodano, Italy) at a $100 \mathrm{X}$ concentration. Working solutions were prepared in culture medium before the experiment. All of the culture media, serum and reagents used were endotoxin free.

Determination of parasite activity - Promastigotes of L. chagasi and epimastigotes of $T$. cruzi parasites were treated with a three-fold dilution series of essential oils, major compounds or reference drugs for $72 \mathrm{~h}$ at $28^{\circ} \mathrm{C}$. The inhibition of parasite growth was microscopically determined by counting parasite numbers in a haemocytometer. For intracellular amastigote assays, Vero cells were infected with tissue-derived trypomastigotes of $T$. cruzi and THP-1 transformed cells were infected with late-stage promastigotes of Leishmania at a 10:1 parasite to cell ratio. After $24 \mathrm{~h}$, infected cells were incubated with the essential oils, major compounds or reference drugs for $72 \mathrm{~h}$ at $37^{\circ} \mathrm{C}$ in a $5 \% \mathrm{CO}_{2}-95 \%$ air mixture. Drug activity was determined by the percentage of infected cells in treated and untreated cultures in methanol-fixed and Giemsa-stained preparations.

Toxicity to mammalian cells - The cell toxicity was tested using the MTT [3-(4,5-dimethylthiazol-2-yl)-2,5diphenyl-tetrazolium bromide)] reduction assay. Vero and transformed THP-1 cells were incubated with each essen- tial oil $(0-100 \mu \mathrm{g} / \mathrm{mL})$ for $72 \mathrm{~h}$ at $37^{\circ} \mathrm{C}$ in a $5 \% \mathrm{CO}_{2}-95 \%$ air mixture. The optical density (OD) of the dissolved formazan crystals was measured using a microplate reader at a wavelength of $580 \mathrm{~nm}$. The percentage of cytotoxicity was calculated using the following equation:

\section{$100 \times$ (OD control - OD treated)/OD control.}

Statistical analysis - The anti-parasite activity was expressed as the concentration required to inhibit 50\% and $90 \%\left(\mathrm{IC}_{50}\right.$ and $\left.\mathrm{IC}_{90}\right)$ of parasite growth. The cell toxicity was expressed as the concentration required for $50 \%$ and $90 \%\left(\mathrm{CC}_{50}\right.$ and $\left.\mathrm{CC}_{90}\right)$ cell killing. They were calculated by sigmoidal regression analyses (Msxlfit ${ }^{\mathrm{TM}}$, ID Business Solution, Guildford, UK). The selective index (SI) was calculated by dividing $\mathrm{CC}_{50}$ Vero cells $/ \mathrm{IC}_{50}$ T. cruzi, or $\mathrm{CC}_{50}$ THP-1 cells $/ \mathrm{IC}_{50}$ L. chagasi. Results were expressed as mean \pm standard deviation and statistical significance was determined by Student's $t$-test ( $p<0.05$ was considered significant). All experiments were repeated twice in quadruplicate. Principal component analysis (PCA) of the composition and biological activity data was performed with Statistica 6.0 software (StatSoft, Tulsa, OK, USA).

\section{RESULTS}

A total of 19 different essential oil samples were obtained from plant material from Lippia alba, Lippia citriodora, Lippia dulcis, Lippia micromera and Lippia origanoides. GC-MS analysis permitted the positive identification of 36 different compounds in relative amounts $\geq 0.5 \%$ (Table II). Although there was not a single compound common to all of the essential oils, a PCA analysis showed compositional similarities amongst the diverse samples. A representation of the sample compositions, in the plane formed by the first two principal components, revealed the presence of four groups of essential oils (Figure): group I was formed exclusively by carvone and limonene-rich $L$. alba oils, group II consisted of citral and trans- $\beta$-caryophyllene-rich oils that corresponded to the L. alba, L. citriodora and L. dulcis species, group III contained carvacrol, thymol and $p$ cymene-rich oils of the L. origanoides and L. micromera species and group IV comprised $L$. origanoides oils in which $p$-cymene was more abundant than carvacrol and thymol, but there were no detectable amounts of thymol methyl ether. Thus, the PCA analysis showed that $L$. alba and L. origanoides belonged to two different chemotypes, a fact that was already reported for such species (Hennebelle et al. 2006, Stashenko et al. 2008).

Table I contains the results of the antiprotozoal and mammalian cell activities for the 19 essential oils examined. Analogous to the compositional data, the corresponding bioactivity data were also subjected to a PCA to compare the bioactivity of the essential oils. Similar to the grouping criterion for the composition, oils in group I maintained a close relationship in bioactivity (Figure). A similar proximity in bioactivity was found within groups III and IV. However, oils in group II appeared rather scattered, indicating that their small compositional differences led to dissimilar bioactivity. A closer look at the bioactivity contrasts and similarities follows. 


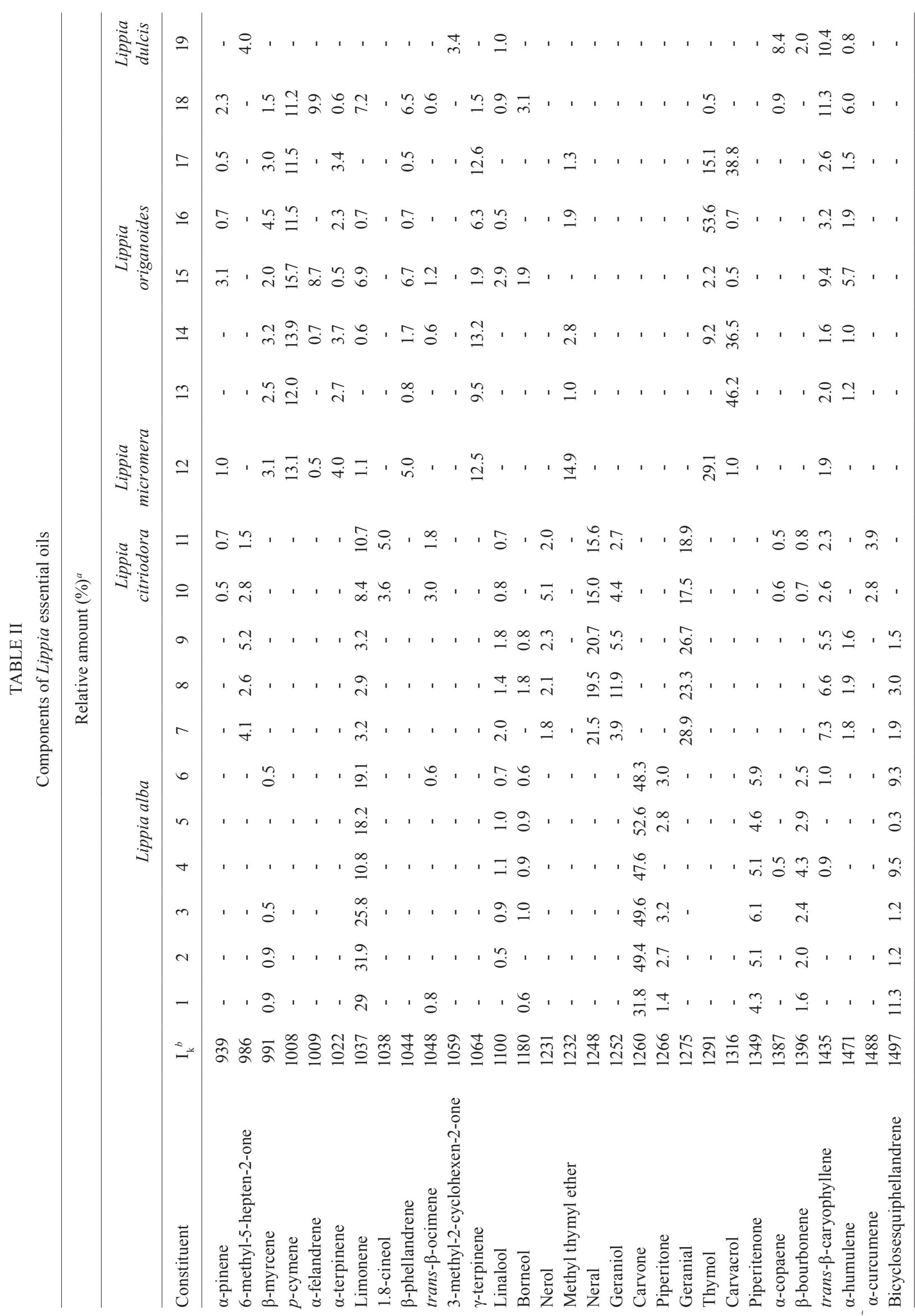




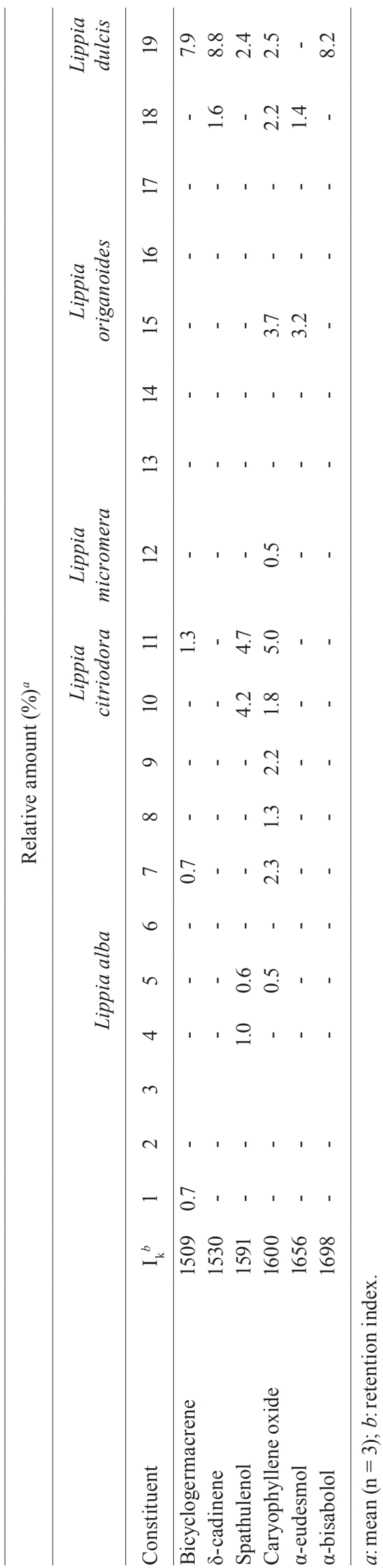

Some essential oils obtained from Lippia plants grown in Colombia were biologically active on parasites and cells (Table I). For T. cruzi, nine oils (7-11, 13 and 17-19) were active on epimastigote parasites with an $\mathrm{IC}_{50}$ in the range of $5.5 \pm 0.4-32.2 \pm 0.2 \mu \mathrm{g} / \mathrm{mL}$ and an $\mathrm{IC}_{90}$ in the range of $11.6 \pm 0.2-90.0 \pm 16.0 \mu \mathrm{g} / \mathrm{mL}$. Six essential oils $(8,9,11,13,17$ and 19$)$ were active on amastigotes interiorised in Vero cells (the $\mathrm{IC}_{50}$ ranged from 12.2 \pm $0.1-53.0 \pm 0.24 \mu \mathrm{g} / \mathrm{mL}$ and the $\mathrm{IC}_{90}$ ranged from $31.4 \pm$ 0.2 to $<100 \mu \mathrm{g} / \mathrm{mL})$. For $L$. chagasi, six oils $(8,10,12,13$, 16 and 17) were active on promastigotes (the $\mathrm{IC}_{50}$ ranged from 5.0 $\pm 1.9-52.0 \pm 1.1 \mu \mathrm{g} / \mathrm{mL}$ and the $\mathrm{IC}_{90}$ ranged from $23.0 \pm 1.7-60 \pm 3.5 \mu \mathrm{g} / \mathrm{mL}$ ). None of the oils were active on amastigotes inside THP-1 macrophages. Six oils $(1,7$, $8,16,18$ and 19) were partially toxic in Vero cells $\left(\mathrm{CC}_{50}\right.$ from 21.0 $\pm 2.3-58 \pm 2.1)$ and two $(7,9)$ were toxic in THP-1 macrophages $\left(\mathrm{CC}_{50}\right.$ from 17.0 $\left.\pm 6.0-43.0 \pm 4.7\right)$.

The essential oils of the Colombian Lippia species we examined were made up of complex mixtures that differed in quantity and type, dependent upon the Lippia species and the place of collection (Table II). The oils derived from L. alba (Miller) N.E. Brown with the highest antiprotozoal activity were composed mainly of geranial, neral, geraniol, trans- $\beta$-caryophyllene and 6-methyl-5-hepten-2-one. They were partially toxic in mammalian cells; however, a SI higher than 2.5 was observed with $T$. cruzi. In contrast, the less active $L$. alba oils contained carvone, limonene, piperitone, piperitenone, $\beta$-bourbonene and bicyclosesquiphellandrene. Both essential oils derived from L. citriodora (syn. Aloysia triphylla) were active on T. cruzi and L. chagasi and had no toxicity in Vero and THP-1 cells. They were composed primarily of geranial, neral, limonene, nerol, 1,8-cineol, spathulenol and caryophyllene oxide. Citral, a monoterpene aldehyde synthesised by several plant genera, is a mixture of geranial and neral with demonstrated biologic activities against other pathogens, especially fungus and bacteria. In addition, citral is the main constituent of the essential oil of lemongrass and has activity against free and intracellular forms of $T$. cruzi parasites (Santoro et al. 2007a). Essential oil from L. citriodora has also demonstrated activity against other microorganisms, such as Candida albicans (Teixeira et al. 2005) and Helicobacter pylori (Ohno et al. 2003). Previously, some oil samples tested in this paper were analysed against fungus and viruses (Meneses et al. 2009, Mesa et al. 2009). The $L$. alba-citral chemotype (Voucher 216929) was screened against Candida parasilosis, Candida krusei, Aspergillus flavus and Aspergillus fumigatus and showed activity against $C$. krusei and A. fumigatus (Mesa et al. 2009). In addition, the essential oils of $L$. alba (Voucher 480750) and L. origanoides (Voucher 512075) were active against yellow fever virus (Meneses et al. 2009).

The antiprotozoal-active essential oil derived from $L$. origanoides H.B.K. showed a high content of oxygenated monoterpenes: sample 13 contained carvacrol $(46.2 \%)$, $p$-cymene $(12 \%)$ and $\gamma$-terpinene $(9.5 \%)$ and sample 17 contained carvacrol (38.8\%), thymol (15.1\%), $\gamma$-terpinene (12.6) and $p$-cymene (11.5\%). These natural constituents also exist in other aromatic plants (i.e., from the Lamiacea family) and plants such as oregano and thyme have shown biological activity against Leishmania spp and $T$. 
TABLE III

Antiprotozoal and mammalian cell activities of the major essential oil components

\begin{tabular}{|c|c|c|c|c|c|c|c|c|c|}
\hline \multirow{4}{*}{ Component } & \multicolumn{9}{|c|}{$\mu \mathrm{g} / \mathrm{mL}$} \\
\hline & \multicolumn{4}{|c|}{ Trypanosoma cruzi } & \multicolumn{3}{|c|}{ Leishmania chagasi } & \multicolumn{2}{|c|}{ Mammalian cells } \\
\hline & \multicolumn{2}{|c|}{ Epimastigotes } & \multicolumn{2}{|c|}{ Amastigotes } & \multicolumn{2}{|c|}{ Promastigotes } & \multirow{2}{*}{$\frac{\text { Amastigotes }}{\mathrm{IC}_{50}{ }^{d}}$} & \multirow{2}{*}{$\begin{array}{c}\text { Vero } \\
\mathrm{CC}_{50}{ }^{e}\end{array}$} & \multirow{2}{*}{$\begin{array}{l}\text { THP-1 } \\
\mathrm{CC}_{50}\end{array}$} \\
\hline & $\mathrm{IC}_{50}$ & $\mathrm{SI}^{a}$ & $\mathrm{IC}_{50}$ & $\mathrm{SI}^{b}$ & $\mathrm{IC}_{50}$ & $\mathrm{SI}^{c}$ & & & \\
\hline Geranial & 3.1 & 30.0 & $>30$ & - & 40.3 & 5.9 & $>30$ & 91.7 & 237.5 \\
\hline S-limonene & 211.2 & 0.5 & $>30$ & - & 129.1 & 1.7 & $>30$ & 113.5 & 215.2 \\
\hline R-limonene & 38.7 & 2.7 & 145.9 & 0.7 & 261.0 & 0.7 & $>30$ & 105.4 & 178.9 \\
\hline Carvacrol & 3.0 & 9.5 & 27.3 & 1.0 & 28.0 & 9.1 & $>30$ & 28.3 & 255.4 \\
\hline$p$-cymene & 28.1 & 4.1 & 190.5 & 0.6 & 149.1 & 1.1 & $>30$ & 115.4 & 157.3 \\
\hline$\gamma$-terpinene & 162.9 & 0.6 & $>30$ & - & 145.1 & 1.3 & $>30$ & 95.9 & 181.7 \\
\hline S-carvone & 139.2 & 1.8 & 6.0 & 42.3 & $>300$ & & $>30$ & 255.5 & 270.9 \\
\hline R-carvone & $>300$ & - & $>30$ & - & 179.1 & 1.0 & $>30$ & 17.2 & 171.6 \\
\hline Thymol & 0.33 & 112.8 & 3.2 & 11.8 & 65.2 & 3.3 & $>30$ & 37.2 & 214.3 \\
\hline
\end{tabular}

$a$ : selective index $\left(\mathrm{CC}_{50}\right.$ on Vero cells/ $\mathrm{IC}_{50}$ on $T$. cruzi epimastigotes); $b: \mathrm{CC}_{50}$ on Vero cells/ $\mathrm{IC}_{50}$ on $T$. cruzi amastigotes; $c$ : $\mathrm{CC}_{50}$ on THP-1 cells/ $\mathrm{IC}_{50}$ on $L$. chagasi promastigotes; $d$ : inhibitory concentration; $e$ : cytotoxic concentration.

cruzi. Interestingly, the essential oils from the Colombian Lippias used in this study do not contain eugenol, but they do have a low concentration of linalool instead (Table II). These two compounds have been active in vitro against L. amazonensis parasites (Ueda-Nakamura et al. 2006). A new chemotype of $L$. alba from Brazil showed a stable high content of linalool (Siani et al. 2002) and would be a good candidate to test against parasites.

In this paper, thymol ( $p$-cymene derivative) was the major component of sample $12(29.1 \%)$ from L. micromera Schauer and sample $16(53.6 \%)$ from L citriodora. Although the former showed low antiprotozoal activity, the latter was the most active against promastigotes of L. chagasi. The activity of thymol derivatives has been demonstrated in vitro and on experimental models of Leishmania panamensis (Robledo et al. 2005).

L. dulcis Trev. oil was composed mainly of trans$\beta$-caryophyllene, $\delta$-cadinene $\alpha$-copaene, $\alpha$-bisabolol and bicyclogermacrene. It was active on $T$. cruzi and $L$. chagasi; however, some toxicity was observed in Vero cells. Oil samples 7-9, 16 and 17 contained trans- $\beta$ Caryophyllene and all of them have induced at least some toxicity on mammalian cells. L. dulcis has demonstrated antiproliferative activity in vitro in different cancer cells. On the other hand, some other plant components, such as demethoxycentaureidin and eupafolin, were toxic to HeLa cells (Abe et al. 2002). It would be interesting to continue exploring the anticancer activity of this plant.

Some major components of the essential oils were biologically active against parasites and in cells. To complement this study, the antiprotozoal and mammalian cell activities of seven of the major components from the active essential oils were tested (Table III). In T. cruzi assays, thymol, carvacrol, geranial and $p$-cymene were active against epimastigotes. The $\mathrm{IC}_{50}$ values ranged from
0.3-28.1 $\mu \mathrm{g} / \mathrm{mL}$, the $\mathrm{IC}_{90}$ values ranged from 3.8-68.8 $\mu \mathrm{g} /$ $\mathrm{mL}$ and the SI was higher than 4. Thymol $\left(\mathrm{IC}_{50} 3.6 \pm 0.4\right.$, $\mathrm{IC}_{90}>30 \mu \mathrm{g} / \mathrm{mL}$, SI 11.8) and S-carvone $\left(\mathrm{IC}_{50} 6.0 \pm 2.2\right.$, $\mathrm{IC}_{90}>30 \mu \mathrm{g} / \mathrm{mL}$, SI 42.3) were active on intracellular amastigotes of $T$. cruzi infected Vero cells. In general, all of the major components were less active on L. chagasi parasites. Carvacrol, geranial and thymol were moderately effective against promastigote forms, but none of them were active against intracellular amastigotes in THP-1 cells (Table III). Differences in cell toxicities were observed between Vero and THP-1 mammalian cells. Sta-

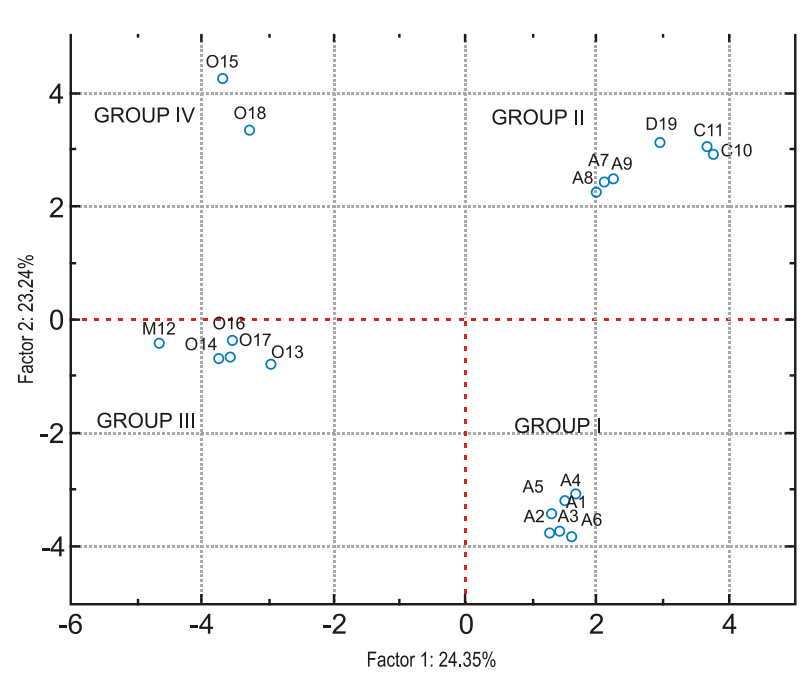

A representation (principal component analysis) of the Lippia essential oils composition in the plane formed by the first two principal components of the composition data. Point labels were constructed with the first letter of the species ( $\underline{a}$ lba, ćitriodora, $\underline{\text { dulcis, }}$ micromera and origanoides) followed by the corresponding oil number in Table I. 
tistically ( $p>0.001)$, they were more toxic in Vero cells compared to THP-1 cells. R-(-)-carvona, carvacrol and thymol were the most toxic components in Vero cells (the $\mathrm{IC}_{50}$ ranged from 17.2-37.2 $\mu \mathrm{g} / \mathrm{mL}$ and the $\mathrm{IC}_{90}$ was $>300$ $\mu \mathrm{g} / \mathrm{mL})$. The effectiveness of thymol on $T$. cruzi $\left(\mathrm{IC}_{50}\right.$ was $62.0 \mu \mathrm{g} / \mathrm{mL}$ after $24 \mathrm{~h}$ of treatment) was demonstrated previously against parasites free of epimastigotes and trypomastigotes (Santoro et al. 2007b). The present paper showed that thymol was effective against intracellular parasitic forms of $T$. cruzi but not against $L$. chagasi amastigotes. This compound was the main constituent of oil sample 12 (L. micromera), as well as 16 and 17 ( $L$. origanoides), and was also present in samples 14, 15 and 18 (L. origanoides), which were active against T. cruzi. Thymol was ineffective against intracellular amastigotes of $L$. chagasi infected THP-1 cells, consistent with what has been demonstrated on intracellular forms of $L$. (Viannia) panamensis (Robledo et al. 2005).

\section{REFERENCES}

Abe F, Nagao T, Okabe H 2002. Antiproliferative constituents in plants. 9. Aerial parts of Lippia dulcis and Lippia canescens. Biol Pharm Bull 25: 920-922.

Braga FG, Bouzada MLM, Fabri RL, Matos M, Moreira FO, Scio E, Coimbra ES 2007. Antileishmanial and antifungal activity of plants used in traditional medicine in Brazil. J Ethnopharmacol 111: 396-402.

Croft SL, Barrett MP, Urbina JA 2005. Chemotherapy of trypanosomiases and leishmaniasis. Trends Parasitol 21: 508-512.

Hennebelle T, Sahpaz S, Dermont C, Joseph H, Bailleul F 2006. The essential oil of Lippia alba: analysis of samples from French overseas departments and review of previous works. Chem Biodivers 3: 1116-1125.

Meneses R, Ocazionez RE, Martínez JR, Stashenko EE 2009. Inhibitory effect of essential oils obtained from plants grown in Colombia on yellow fever virus replication in vitro. Ann Clin Microbiol Antimicrob, in press.

Mesa AC, Montiel J, Zapata B, Durán C, Betancur L, Stashenko E 2009. Citral and carvone chemotypes from the essential oils of Colombian Lippia alba (Mill.) N.E. Brown: composition, cytotoxicity and antifungal activity. Mem Inst Oswaldo Cruz 104: 878-884.

Mikus J, Harkenthal M, Steverding D, Reichling J 2000. In vitro effect of essential oils and isolated mono- and sesquiterpenes on Leishmania major and Trypanosoma brucei. Planta Med 66: 366-368.

Monzote L, Montalvo AM, Scull R, Miranda M, Abreu J 2007. Activity, toxicity and analysis of resistance of essential oil from Chenopodium ambrosioides after intraperitoneal, oral and intralesional administration in BALB/c mice infected with Leishmania amazonensis: a preliminary study. Biomed Pharmacother 61: 148-153.

Ohno T, Kita M, Yamaoka Y, Imamura S, Yamamoto T, Mitsufuji S, Kodama T, Kashima K, Imanishi J 2003. Antimicrobial activity of essential oils against Helicobacter pylori. Helicobacter 8: 207-215.
Pascual ME, Slowing K, Carretero E, Mata D, Villar A 2001. Lippia: tradicional uses, chemistry and pharmacology: a review. J Ethnopharmacol 76: 201-214.

Robledo S, Osorio E, Muñoz D, Jaramillo LM, Restrepo A, Arango G, Velez I 2005. In vitro and in vivo cytotoxicities and antileishmanial activities of thymol and hemisynthetic derivates. Antimicrob Agents Chemother 49: 1652-1655.

Rosa MdoS, Mendoca-Filho RR, Bizzo HR, Almeida Rodriguez I, Soares RM, Souto-Padrón T, Alviano CS, Lopes AH 2003. Antileishmanial activity of a linalool-Rich 2essential oil from Croton cajucara. Antimicrob Agents Chemother 47: 1895-1901.

Sanchez AM, Jimenez-Ortíz V, Sator T, Tonn CE, García EE, Nieto M, Burgos MH, Sosa MA 2006. A novel icetexane diterpene,5epi-icetexone from Salvia gilliessi is active against Trypanosoma cruzi. Acta Trop 98: 118-124.

Santoro GF, Cardoso MG, Guimarães LG, Freire JM, Soares MJ 2007a. Anti-proliferative effect of the essential oil of Cymbopogon citratus (DC) Stapf (lemongrass) on intracellular amastigotes, bloodstream trypomastigotes and culture epimastigotes of Trypanosoma cruzi (Protozoa: Kinetoplastida). Parasitology 134: 1649-1656.

Santoro GF, Cardoso MG, Guimarães LG, Salgado AP, Mena-Barreto RF, Soares MJ 2007b. Effect of oregano (Origanum vulgare L.) and thyme (Thymus vulgaris L.) essential oils on Trypanosoma cruzi (Protozoa: Kinetoplastida) growth and ultrastructure. $\mathrm{Pa}$ rasitol Res 100: 783-790.

Siani AC, Tappin MR, Ramos MF, Mazzei JL, Ramos MC, De Aquino Neto FR, Frighetto N 2002. Linalool from Lippia alba: study of the reproducibility of the essential oil profile and the enantiomeric purity. J Agric Food Chem 50: 3518-3521.

Stashenko EE, Jaramillo BE, Martínez JR 2004. Comparison of different extraction methods for the analysis of volatile secondary metabolites of Lippia alba (Mill.) N.E. Brown, grown in Colombia, and evaluation of its in vitro antioxidant activity. $J$ Chromatogr A 1025: 93-103.

Stashenko EE, Ruiz C, Muñoz A, Castañeda M, Martínez J 2008. Composition and antioxidant activity of essential oils of Lippia origanoides H.B.K. grown in Colombia. Nat Prod Commun 3: 563-566.

Tan N, Kaloga M, Radtke OA, Kiderlen AF, Oksüz S, Ulubelen A, Kolodziej H 2002. Abietane diterpenoids and triterpenoic acids from Salvia cilicica and their antileishmanial activities. Phytochemistry 61: 881-884.

Teixeira Duarte MC, Figueira GM, Sartoratto A, García Rehder, Delarmelina C 2005. Anti-Candida activity of Brazilian medicinal plants. J Ethnopharmacol 97: 305-311.

Ueda-Nakamura T, Mendonça-Filho RR, Morgado-Díaz JA, Korehisa MP, Prado Dias FB, Aparício Garcia Cortez D, Alviano DS, Rosa Mdo S, Lopes AH, Alviano CS, Nakamura CV 2006. Antileishmanial activity of Eugenol-rich essential oil from Ocimum gratissimum. Parasitol Int 55: 99-105. 